\title{
Research Note \\ Environmental Inputs and Outputs in Ecotourism: Geotourism with a Positive Triple Bottom Line?
}

\author{
Ralf Buckley \\ International Centre for Ecotourism Research, Griffith University, Queensland, \\ Australia
}

The main defining characteristics of ecotourism fall into two categories, namely environmental inputs and environmental outputs. The inputs are the natural and associated cultural features in a particular geographic place which serve as attractions for tourists. The outputs are the net costs or benefits for the natural and social environment. Ecotourism can hence be viewed as geotourism with a positive triple bottom line. There are several advantages to this approach. (1) It clarifies the meaning of ecotourism without redefining it. (2) It bypasses the service components which are common to tourism in general, not distinctive to ecotourism. (3) It treats environmental management and interpretation as means, not ends. (4) It requires an accurate accounting of environmental and social, as well as financial, costs as well as benefits. (5) It differentiates ecotourism from tourism products with a mere veneer of green. (6) The tourism products and organisations which are generally viewed as the world's best practice in ecotourism do comply with this definition.

\section{Introduction}

Ecotourism is a complex concept. The Quebec Declaration (UNEP/WTO, 2002), the top-level output of the International Year of Ecotourism, uses over 80 words and at least five distinct criteria. These boil down to: nature-based product, minimal-impact management, environmental education, contribution to conservation and contribution to communities. But it is still difficult to define whether an individual product or project qualifies as ecotourism (Buckley, 2003). Can we express the concept of ecotourism in a way which is both more precise and more succinct? Or is the concept of ecotourism necessarily nebulous, a series of scales in five different dimensions? And does it matter? Perhaps it does. For ecotourism to exert any significant influence on large-scale practice and policy, for example, governments will want economic statistics; and to collect these, statistical agencies will need clear criteria.

\section{Sources of Uncertainty}

The current lack of precision may be considered in four categories. The first source of uncertainty is about each criterion independently. For example, must the product be nature-based, or can it also be culture-based? If the former, where is the dividing line? If the latter, which cultures and cultural manifestations are included? If an indigenous tour guide describes plant and animal names, traditional uses and mythology, is that nature or culture-based? If visiting the cultures of indigenous peoples living traditional lifestyles is ecotourism, what about 
indigenous peoples on their own land but with oil royalties and western speedboats or snowmobiles? And if the latter, then why not, say, English country estates? Or if poverty is a precondition, why not ghetto gangs?

Similarly, sustainability is vague, and minimal-impact means little without a comparative framework. For example, is it enough for a helicopter tour to use a low-noise machine, or should the client have to walk? And what if a parks agency promotes helicopter overflights in preference to hiking on fragile landforms?

The second source of uncertainty is in combining criteria. Must they all be satisfied, or only some, and if so in what combination? And to what degree can good performance on one criterion compensate for poor performance on others? Can a green spiel from the guide compensate for a company's impacts on the environment, or is that merely hypocritical? Historically, it is this issue which has been debated most in defining ecotourism. In particular, commercial interests in some countries have focused strongly on nature-based products, with limited attention to management and education, and little or none to conservation or communities.

The third source of uncertainty is in quantifying performance against each criterion. If a company makes a contribution to conservation, for example, which represents only a few tenths of a percent of revenue, is this large enough to count? If not, what should the threshold be? If a hotel simply puts placards in guest rooms, telling guests they can save water by not having their towels washed every day, is this a significant improvement in environmental management? If a lodge prints brochures advertising a walk in a nearby park, is that environmental interpretation?

The fourth source of uncertainty is in baselines or benchmarks for comparison. If company A barely complies with relatively stringent environmental standards in one country, whereas company B far surpasses much lower standards in another country but still does not match the actual performance level of company A, which should be judged closer to ecotourism principles? In addition, different types of tour operations typically have very different options available to improve environmental management. Instead of assessing what an enterprise has achieved relative to minimum legally-mandated standards, should we assess performance relative to best practice by similar enterprises elsewhere?

\section{Inputs and Outputs}

This all sounds very complicated, but it boils down to just two independent issues: the environmental input and the environmental output. The environmental input is the primary attraction: not the level of service or facilities provided as part of a product package, but the geographical factor which has led the tourist to a particular destination. The environmental output is the overall net global cost or benefit of the tour operation to the natural environment. This is an accounting question, which requires the identification, quantification and summation of all costs and benefits through all potential mechanisms, of which there are many.

Importantly, this approach completely bypasses the service components of a retail tourism product, effectively treating it instead as a black box. From a business perspective these components are vital, but they do not differentiate ecotourism from any other form of tourism. In particular, if an interpretation 
programme keeps clients happy but does not reduce their impacts, then it is a component of service rather than a contribution to the environment.

This conceptual approach does not move the meaning of ecotourism outside its currently accepted boundaries, but can clarify them considerably. In particular, it highlights a number of critical issues, some on the input side and some on the output.

One such distinction is between nature and culture, natural and social environment. Historically, 'local communities' have been an oft-quoted touchphrase in the ecotourism literature, but with confusion between input and output aspects. On the input side, the critical question is whether an attraction which relies principally on some aspect of human culture, rather than nature alone, should be considered as ecotourism. On the output side, the question is whether purely social costs and benefits are significant in themselves, or only in so far as they affect the impacts of those societies on the natural environment.

Fortunately, though significant both in principle and in politics, this distinction is rather unimportant in practice. Cultural tours do not seem to be marketed as ecotours in practice, except for traditional cultures with strong links to local natural environments. Equally, practical case studies indicate that for ecotourism to assist in conservation of the natural environment, it must provide some benefit, tangible or otherwise, for people in a position to protect that environment.

Under the conceptual approach suggested here, minimal-impact management is not a fundamental criterion in itself, but a way to reduce environmental costs; and the critical issue is to assess the total cost, not how much it may or may not have been reduced relative to various alternative possible benchmarks. Environmental interpretation is not a goal in itself, but simply one of many potential mechanisms to produce an environmental benefit. Again, it is the benefits that matter, more than the mechanism.

Under this approach, ecotourism is tourism which satisfies both the input and output criteria as outlined above. In practice, tourism products which yield a net benefit for the global environment are nearly all nature-based, but this need not necessarily be so. The proprietor of an urban hotel, for example, could use profits to establish private conservation reserves. This is uncommon, but not unknown.

\section{Geotourism as an input term}

It would certainly be convenient if there were distinct terms to identify the input and output factors separately. Phrases such as 'tourism in a natural setting', however, are too vague, for the reasons outlined earlier. To date, most attempts to define the input aspect more precisely have done so by aggregating subsectors. The term NEAT (Buckley, 2000), for example, aggregates more contemplative nature tourism with more excitement-based adventure tourism. The term ACE (Fennell, 1999) adds the cultural component to the mix, subject to all the issues discussed earlier. Whilst useful analytically, however, such acronyms do not seem to have been adopted in marketing materials or policy documents.

One potential term which could indeed catch on more broadly is geotourism (Stueve et al., 2002). Currently, this term is used in two distinct senses, neither quite matching what we need in the current context. The older use of the term is 
as shorthand for geological tourism, travelling to see rocks. This is a rather small specialist subsector! The more recent use, as defined by the Travel Industry Association of America and National Geographic (Stueve et al., 2002) is essentially the same as ecotourism in the sense of the Quebec Declaration: including both input and output components, and including cultural and social components in both.

Since the TIAA/NG geotourism report was released, the term has taken off quickly. For example, it appears in the title of several papers at the International Ecotourism Conference at Cairns in October (EAA, 2002). Given the usual turnover time for academic publication, we cannot yet check if it has been adopted in journal articles! The way in which the term is being used in practice, however, seems rather different from the way its authors define it. Rather, it corresponds closely to the term we are looking for: i.e. tourist attractions, either natural or cultural, which are specific to one geographic place. In this sense, geotourism excludes business travel, VFR, MICE, 3S, generic resorts, casinos, theme parks and similar forms of mass tourism. If you travel to see particular scenery or wildlife or experience a particular local culture, climb a particular mountain or kayak a particular river, then in this sense you would be a geotourist. If you want to lie on the beach, visit nightclubs or casinos, play golf or go bungy jumping, however, and don't particularly care where, then you are not. Only if you insist on a specific casino, golfcourse or bungy jump, such as Las Vegas, St Andrews or Karamea Bridge respectively, will you qualify as a geotourist.

\section{Triple-bottom-line accounting for output}

On the output side, perhaps the most promising approach at present is so-called triple-bottom-line accounting, where environmental, social and financial costs and benefits are assessed independently, and the company is not in credit unless all three bottom lines are positive. This is not the same as sustainability, in the fundamental sense of keeping the planet in a livable state. It is, however, a useful step which recognises that such sustainability can only be achieved through major changes to human social structure and behaviour, and that social and environmental accounting may be one tool to promote such changes.

All definitions of ecotourism also include sustainability as a key criterion, but this has done little to clarify its meaning. The underlying issue of sustainability is clear enough: if the human species causes too much damage to the rest of the planet, then that species will not survive; and meanwhile the more damage to the planet caused by current human generations, the worse shape the planet will be in as a resource for future generations.

Establishing social structures and institutions which can change human behaviour sufficiently to reduce present-day damage to the global environment, however, is almost intractably difficult, because of the complexity of current human societies. Sustainability is fundamentally about human interactions with the natural environment; but any attempt to get there depends on human interactions with other humans. Hence the triple-bottom-line (3BL) approach, including money and politics as well as the planet. Of course, the 3BL approach is subject to widespread political misuse: an excuse to divert attention away from environmental issues, disguise environmentally destructive practices and policy, dilute environmental research efforts and disarm environmental activ- 
ists. Used constructively, however, the 3BL concept may perhaps lead voters and consumers to weigh the environmental and social aspects of products and policies as well as price and profit.

Businesses in all industry sectors have begun preparing 3BL sustainability assessments, similar to the various corporate environmental reporting initiatives over the past few years. In most of these, the social and environmental components are a great deal less detailed than the financial figures. For example, they may list the appointment of environmental advisors, the adoption of an environmental management system, or the sustainability report itself as environmental achievements, with no attempt to account for environmental costs and benefits across the company's entire operations. For comparison, a company's financial statements would not be well received by regulators and sharemarkets if they said only that the company thought money was important, had established a financial management system, and had appointed some financial advisors!

At present, corporations and governments have much more detailed financial information than environmental or social; but this is largely because they spend far more effort on collecting financial information. For any organisation to show that it has a positive social or environmental bottom line, in any meaningful accounting sense, it needs to identify and quantify all the direct and indirect environmental and social costs and benefits of its entire operations, and calculate the difference between the benefits and the costs. This is very different from arguing that money and jobs outweigh environmental costs. A positive triple bottom line means a net improvement in conservation of the natural environment and a net social benefit for local communities, as well as a net profit for shareholders and/or a net gain for national or regional economies.

Strictly speaking, a distinction can be made between a financial bottom line for shareholders, and an economic bottom line for a regional economy. The latter, however, may be viewed as part of the social bottom line, contributing to society beyond the shareholders themselves.

Very few organisations worldwide can demonstrate a positive triple bottom line. Most of these are either environmental organisations, environmental technology and services companies, or ecotourism enterprises. Of these, the first two are established specifically to counteract or remediate the environmental impacts of other sectors. Currently, tourism seems to be the only major industry sector where there are individual commercial enterprises which generate net gains for conservation, communities and shareholders simultaneously. These enterprises seem to be precisely what we think of as ecotourism, which can therefore be conceived of as geotourism with a positive triple bottom line.

\section{Advantages of a Bottom-line Focus}

Whilst fundamentally the same as more complex definitions of ecotourism such as that used by UNEP/WTO (2002), the conceptual approach proposed here does differ in emphasis, as noted earlier. Instead of listing environmental education and management as criteria or goals in their own right, the 3BL approach treats them simply as mechanisms, with the goal and criterion being the positive triple bottom line.

This focus on the bottom line has several advantages. One often-asked 
question is, why make such a fuss about ecotourism when there is no equivalent term in other industry sectors, or certainly not one of sufficient significance to have its own UN International Year? The reason, surely, is that whilst enterprises in other sectors can indeed take steps to reduce their operational environmental impacts, their environmental bottom line is still negative. It is only in tourism that there is a realistic opportunity to produce a positive environmental and indeed social bottom line at the same time as a positive economic bottom line. It is thus the positive contribution to conservation, either directly or through local communities, which makes ecotourism worth worrying about. These bottom line contributions, therefore, are the key defining feature.

The key advantage of the bottom-line focus is that to assess a bottom line requires a full and transparent accounting of all the costs as well as the benefits. Done thoroughly, this forces both the ecotourism enterprise and also its shareholders, clients, staff, regulators and local communities, to identify and weigh up those costs and benefits much more fully than is common at present. It is no longer enough simply to list a few benefits and ignore the costs. This in turn should eliminate many of the enterprises which might be described as fake ecotourism or ecotourism lite: where the cosmetic addition of an environmental interpretation programme or a minor improvement in environmental management is used to lay claim to the ecotourism title, even if overall the social and environmental impacts of the enterprise are quite severe. One of the major weaknesses of most tourism ecocertification schemes, for example, is that an enterprise can gain green ticks for hiring good interpretive guides, or indeed for buying plantations far away to offset its carbon dioxide emissions, even if its operations cause loss of biodiversity through disturbance in a national park or clearance of habitat for endangered species. Certification can be a valuable tool, but easily abused - just as Iraq wanted a UN blue tick for its weapons programme.

\section{Practical examples}

So, are there in fact any examples of geotourism with a positive triple bottom line? Yes, but not many (Buckley, 2002, 2003; WTO, 2002). There are private companies which have bought areas of freehold land and established them as conservation reserves funded by ecotourism. Often this includes rehabilitation of vegetation and restocking with wildlife. If the net environmental benefits from the private reserve outweigh the environmental impacts of the tourism operations, then the environmental bottom line is positive. Some of these companies also include community development programmes, e.g. through funds established for community health and education facilities, so the social bottom line may also be positive. Some of these enterprises are very strong economically, whilst others have suffered a series of vicissitudes. Since they still survive, however, the financial bottom line must also be positive overall. These enterprises can thus lay a justifiable claim to a positive triple bottom line.

There are also a number of ecotourism enterprises, either privately or communally owned, which operate successfully on community lands. Where such enterprises allow these communities to retain their lands in a relatively undisturbed state rather than clearing them for agriculture, leasing them for logging, or hunting wildlife for bushmeat or wildlife trade, then a positive triple bottom line is also possible. Similar considerations may apply where large environmen- 
tal NGOs buy land for conservation and operate ecotourism ventures there, or where public land management agencies turn their hand to tourism from other primary production sectors, or where aid programmes establish ecotourism ventures as a long-term source of community income.

As in all accounting exercises, defining the boundaries of the accounting unit is a critical step in assessing a triple bottom line for a tourism or ecotourism enterprise. Just as a large business may have profitable and unprofitable subsidiaries, a tourism company may own or operate particular lodges or tours which do have a positive triple bottom line, and others which do not. Thus, for example, the Australian Nature and Ecotourism Accreditation Program offers ecocertification for individual tourism products, not entire tourism companies (EAA, 2002). If a private reserve and ecolodge, for example, can demonstrate a positive triple bottom line in its operations, it makes no difference whether the initial investment capital was provided by shareholders, a bank loan, or a private corporation which may also have interests in mining or manufacturing, farming or fisheries. For the investor, the net bottom line for the ecotourism enterprise is simply one component to be added into its overall accounts. From the viewpoint of the individual ecotourism operation, the source of capital is irrelevant.

\section{Conclusions}

Thinking of ecotourism as geotourism with a positive triple bottom line is (thankfully!) not a new definition, but simply a way of combining developing concepts of sustainability accounting with developing concepts of tourism market segmentation. It requires a departure from the formal definition of geotourism as proposed by Stueve et al., (2002); but one which seems in any event to be happening in practice. And it could be a useful way to assist in transferring ecotourism principles to mainstream tourism, where the adoption of triple-bottom-line accounting has already commenced.

\section{Correspondence}

Any correspondence should be directed to Ralf Buckley, Director, International Centre for Ecotourism Research, Griffith University, Parklands Drive, Southport, Australia (r.buckley@griffith.edu.au).

\section{References}

Buckley, R.C. (2000) NEAT trends: Current issues in nature, eco and adventure tourism. International Journal of Tourism Research 2, 437-444.

Buckley, R.C. (2002) A global triple-bottom-line evaluation for ecotourism. World Ecotourism Summit, Quebec.

Buckley, R.C. (2003) Case Studies in Ecotourism. Wallingford: CABI.

Ecotourism Association of Australia (2002) www.ecotourism.org.au. Last viewed 1 October 2002.

Fennell, D.A. (1999) Ecotourism: An Introduction. London: Routledge.

Stueve, A.M., Cock, S.D. and Drew, D. (2002) The Geotourism Study: Phase I Executive Summary. www.tia.org/pubs/geotourismphasefinal.pdf. Last viewed 20 September 2002.

UNEP and WTO (2002) Quebec Declaration on Ecotourism. mes/Quebec-Declar-eng.pdf. Last viewed 20 September 2002.

World Tourism Organisation (2002) Sustainable Development of Ecotourism: A Complication of Good Practices (p. 261). Madrid: WTO. 